\title{
Morphological and molecular differentiation of wild and farmed gilthead sea bream Sparus aurata: implications for management
}

\author{
Tanja Šegvić-Bubić ${ }^{1, *}$, Igor Talijančić ${ }^{2}$, Leon Grubišićc ${ }^{1}$, David Izquierdo-Gomez ${ }^{3}$, \\ Ivan Katavić ${ }^{1}$ \\ ${ }^{1}$ Institute of Oceanography and Fisheries, PO Box 500, Šetalište Ivana Meštrovića 63, 21000 Split, Croatia \\ ${ }^{2}$ University Department of Marine Studies, University of Split, Livanjska 5/III, 21000 Split, Croatia \\ ${ }^{3}$ Department of Marine Sciences and Applied Biology, University of Alicante, PO Box 99, 03080 Alicante, Spain
}

\begin{abstract}
A combination of molecular and morphological characteristics was used to investigate populations of wild and farmed gilthead sea bream Sparus aurata from the largest Croatian shellfish production area, Mali Ston Bay. Identification of farmed escapees was performed in the wild in order to evaluate and compare the detection sensitivity of molecular and morphological tools. Using a traditional set of measurements and a truss network system, morphometric trait analysis of gilthead sea bream showed clear body shape differences between individuals from the wild and farmed populations. Microsatellite markers only revealed weak neutral genetic differentiation between farmed and wild samples from Mali Ston Bay (Wright's $F_{\mathrm{ST}}=0.019, \mathrm{p}>0.05$; Jost's $D_{\text {EST }}=0.022$ ), despite the fact that the farmed gilthead sea bream were of Atlantic origin. Using assignment tests, morphological (16\%) and molecular $(25 \%)$ analysis identified farmed escapees in the samples of wild gilthead sea bream in the vicinity of aquaculture sites. Morphological data showed good potential for distinguishing recent escapees in wild populations, since these characteristics are affected by the environment. This study demonstrates the presence of escapees in the local wild population in this region, and suggests the potential for genetic interaction.
\end{abstract}

KEY WORDS: Aquaculture $\cdot$ Sparus aurata $\cdot$ Escape $\cdot$ Microsatellite DNA $\cdot$ Morphology

\section{INTRODUCTION}

Gilthead sea bream Sparus aurata L. are one of the most important and consolidated species in Mediterranean aquaculture, with a production of 154608 metric tonnes in 2011 (FAO 2013). The leading producer countries of gilthead sea bream are Greece, Turkey, Spain, and Italy. Croatia's production of gilthead sea bream is relatively small compared to the rest of the Mediterranean region. In 2012, approximately 29 small family-size marine fish farms produced $2400 \mathrm{t}$ of gilthead sea bream. This, together with sea bass production, accounts for $1.7 \%$ of the total worldwide aquaculture production (FEAP

\footnotetext{
*Corresponding author: tanja.segvic@izor.hr
}

2013). The capacities of domestic hatcheries are still insufficient to satisfy farmer demand for larvae and fingerlings. Consequently, more than $70 \%$ of fingerlings are imported. These fingerlings mainly arise from Italian and French hatcheries, i.e. Atlantic broodstocks, because of their superior growth performance when compared to gilthead sea bream of Mediterranean origin (Miggiano et al. 2005).

Even though gilthead sea bream have been farmed for more than $20 \mathrm{yr}$, the genetic structure of wild populations has only recently been investigated. The application of different nuclear molecular markers at different geographic scales has demonstrated contradictory results, indicating either a weak genetic

() The authors 2014. Open Access under Creative Commons by Attribution Licence. Use, distribution and reproduction are unrestricted. Authors and original publication must be credited. 
structure in the Atlantic and Mediterranean Sea (Alarcón et al. 2004, De Innocentiis et al. 2004, Rossi et al. 2006) or a strong genetic subdivision at short distances along the Tunisian (Ben Slimen et al. 2004) and Croatian coasts (Šegvić-Bubić et al. 2011a). On the other hand, fish farmed throughout the Mediterranean generally form genetically distinct groups compared to their proximal wild populations (Alarcón et al. 2004, Karaiskou et al. 2009, Loukovitis et al. 2012). Such a pattern can be useful in escapee allocation by using molecular markers.

One of the main problems linked with cage aquaculture is the escape of domesticated individuals from farms and their dispersal into the wild. Farmed escapees can affect wild populations through (1) predation and competition for food, (2) spatial and breeding opportunities, (3) the spread of parasites and diseases, and (4) interbreeding with wild fish (Jonsson \& Jonsson 2006, Grigorakis \& Rigos 2011). Escaped gilthead sea bream are able to survive for months in the wild (Arechavala-Lopez et al. 2011, 2012a), where they can interact with local fish populations, potentially changing the genetic structure of the latter through introgression. In Atlantic salmon Salmo salar L., for example, where high numbers of farmed fish have been escaping over several decades, genetic changes as a result of farmed fish introgression have been observed in a number of wild populations (Skaala et al. 2006, Glover et al. 2012, 2013).

An increase in farmed escapees has been recorded in fisheries landings during recent years in Mediterranean coastal areas. These have been identified by external characteristics such as deeper body height, thicker and darker skin, eroded fins with a sharper dorsal fin, and the presence of fewer scales with regenerated nuclei (Arechavala-Lopez et al. 2013). More specifically, the fisheries landings of gilthead sea bream in Croatia have doubled in recent years, from $33 \mathrm{t}$ in 2009 to $74 \mathrm{t}$ in 2012 (Croatian Bureau of Statistics 2013). Due to the increased abundance of gilthead sea bream and the population densitydependent mechanism, a decrease in the average size of gilthead sea bream was observed in landings from the Mesolonghi-Etoliko lagoons, accompanied by a decrease in the total income from sales of the species (Dimitriou et al. 2007). Intentional mislabeling of farmed fish as wild occurs in fish markets and restaurants, leading to customer deception. To overcome issues with fish origin identification, one of the main goals of the Prevent Escape project, funded by the European Union's Seventh Framework Programme for Research (FP7), was to develop fast, accurate, and cost-effective tools for identifying escapees in wild populations. External appearance and morphometry indices were recommended for rapid assessment in the field, trace elements in scales and fatty acid profiles were recommended for fisheries, and environmental management applications and genetic methods were recommended for discrimination of farmed and wild fish, with a high degree of accuracy. Previously, genetic tools have been successfully used to trace the farm of origin for domesticated Atlantic salmon escapees, and have led to fines for companies in breach of regulations (Glover et al. 2008, Glover 2010).

Recently, a decline in mussel production (Mytilus galloprovincialis L.) has been recorded, caused by intense wild gilthead sea bream predation (ŠegvićBubić et al. 2011b), especially in Mali Ston Bay, Croatia's largest shellfish production area. A permanent mussel food source in the bay allows farmed escapees greater opportunities for survival and reproduction. Since Mali Ston Bay is classified as a marine protected area (MPA) where only farming is allowed, assessment of gilthead sea bream origin and quantification of escapees is important for fish and shellfish farmers, and also for environmental managers.

The aim of the study was to assess characteristics for molecular and morphological differentiation from sampled populations of wild and farmed gilthead sea bream from Mali Ston Bay in Croatia. In addition, farmed-escapee identification was performed in a wild population using assignment and classification tests in order to evaluate and compare the detection sensitivity of the molecular and morphological tools.

\section{MATERIALS AND METHODS}

\section{Fish sampling}

A total of 168 gilthead sea bream Sparus aurata adults were collected from 2 wild and 1 farmed populations in the central and southern Adriatic Sea (Brač Channel and Mali Ston Bay; Fig. 1) during the period May-October 2012. Mali Ston Bay represented the farming-impacted area, while Brač Channel served as an unimpacted area without farming activities. The farmed gilthead sea bream from Mali Ston Bay were in the second year of age $(\mathrm{n}=44$; TL $[$ mean $\pm \mathrm{SD}]=213.2 \pm 47.5 \mathrm{~mm}$; weight [mean $\pm \mathrm{SD}$ ] $=201.02 \pm 127.7 \mathrm{~g}$ ), and most sampled fish were males. Reared fish originated from the Atlantic broodstock of gilthead sea bream domesticated in a commercial French hatchery. The farm facility in 


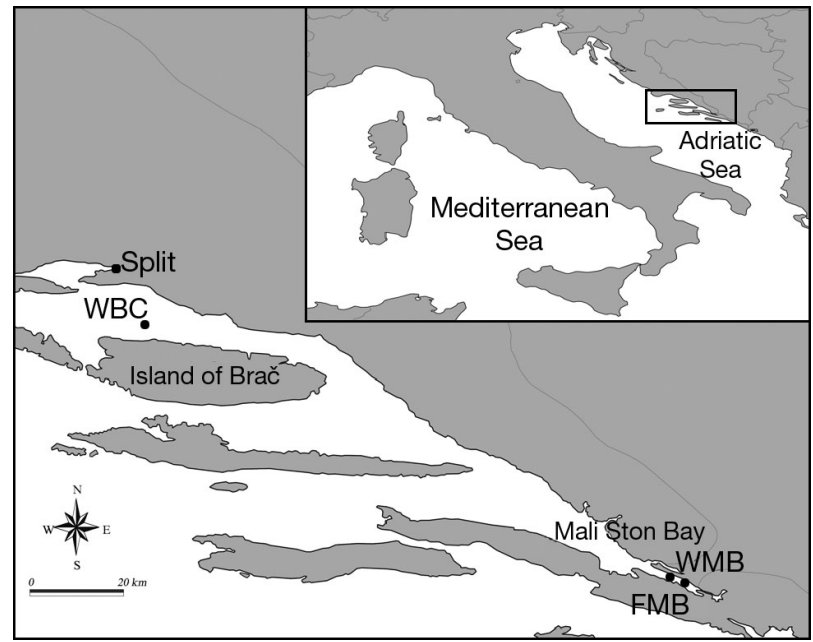

Fig. 1. Sampling locations of gilthead sea bream Sparus aurata along the eastern Adriatic Sea coast. Inset: central/ southeastern Europe, with the sampling area outlined with a rectangle. WBC: wild population from Brač Channel; WMB, FMB: wild and farmed populations from Mali Ston Bay

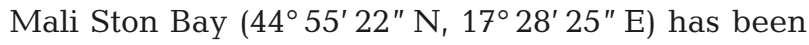
in operation since 1997 with fingerlings of French origin and has an annual finfish production capacity of $50 \mathrm{t}$. It represents 1 of 3 main farms in the region, which together occupy a concession area of $49300 \mathrm{~m}^{2}$ and produce $53 \mathrm{t}$ of gilthead sea bream. The wild population from Mali Ston Bay was composed mostly of males with a $15 \%$ female contribution $\left(\mathrm{n}=94, \mathrm{TL}_{\mathrm{t}}\right.$ $[$ mean $\pm \mathrm{SD}]=294.28 \pm 50.2 \mathrm{~mm}$; weight $[$ mean $\pm \mathrm{SD}]$ $=379.45 \pm 198.28 \mathrm{~g}$ ), and was sampled near the farm using a spear gun and fish hooks in the depth range of 15-30 m within the period of $1 \mathrm{mo}$. All wild and farmed fresh samples from Mali Ston Bay were included in the morphological analysis. The right pectoral fins of the Mali Ston Bay subsample (50 wild and 30 farmed fish) were fixed in $100 \%$ ethanol for molecular analysis and later for combined morphometric-molecular analysis. During July 2012, 30 wild individuals were sampled using a spear gun and fish hooks from Brač Channel $\left(43^{\circ} 25^{\prime} 23^{\prime \prime} \mathrm{N}\right.$, $\left.16^{\circ} 30^{\prime} 60^{\prime \prime} \mathrm{E}\right)$, an area free of any farming activities, and thus served as a control population. This group was used only for molecular analysis since whole fish were not available for morphological testing.

\section{Morphological data}

Morphometric traits of gilthead sea bream were investigated using a traditional set of measurements (Hubbs \& Lagler 1947) and the truss network system
(Bookstein 1982). In total, 19 morphometric characters were measured for the traditional set of measurements and 12 for the truss network system (Fig. 2, Table 1). This combined approach was used to ensure the maximum extraction of morphometric differences between wild and farmed individuals (and to evaluate the most suitable method for their distinction). All morphometric characters were measured with electronic digital calipers to the nearest $0.1 \mathrm{~mm}$ by a single person, in order to minimize error. Fish were placed on acetate sheets where body posture and fins were teased into a natural position. A block of expanded polystyrene was placed beneath the acetate sheet to facilitate pinning. Fulton's condition index (Fulton's $K=10^{5} \times$ body weight / standard length ${ }^{3}$ ) was also computed from length and weight measurements.

\section{Analysis of morphological data}

Differences between morphometric characters of wild and farmed gilthead sea bream obtained from the traditional set of measurements were analyzed using an independent $t$-test $(\mathrm{p}<0.05)$. Further, Cohen's effect size value $(d)$ was calculated in order to present the size-magnitude of differences between wild and farmed individuals. Cohen (1992) defined effect sizes as small $(d=0.2)$, medium $(d=$ $0.5)$ and large $(d=0.8)$. Using Gpower v. 3 software, the statistical power of morpho-characteristic ratios (see McHugh 2008) was calculated to test if the statistical significance obtained by the $t$-test had insufficient power $(<0.80)$ due to an inadequate sample size. Prior to the multivariate analysis of morphometric landmarks obtained from the truss network system, size-dependent variations of all characters were reduced using the transformation method described by Reist (1985). Transformation was performed for each individual in the overall sample. Principal component analysis (PCA), with varimax rotation, was used in the analysis of truss data to evaluate the contribution of 24 morphological vectors on the fish shape configuration. All PCAs having eigenvalues greater than 1 were considered important. Upon defining component loadings on the morphological vector, a cut-off value of 0.5 was set in order to suppress coefficients with small contribution. Stepwise discriminant analysis based on the generalized Mahalanobis distance was carried out to identify which truss network variables contributed significantly to population differences and thus predict population membership. 

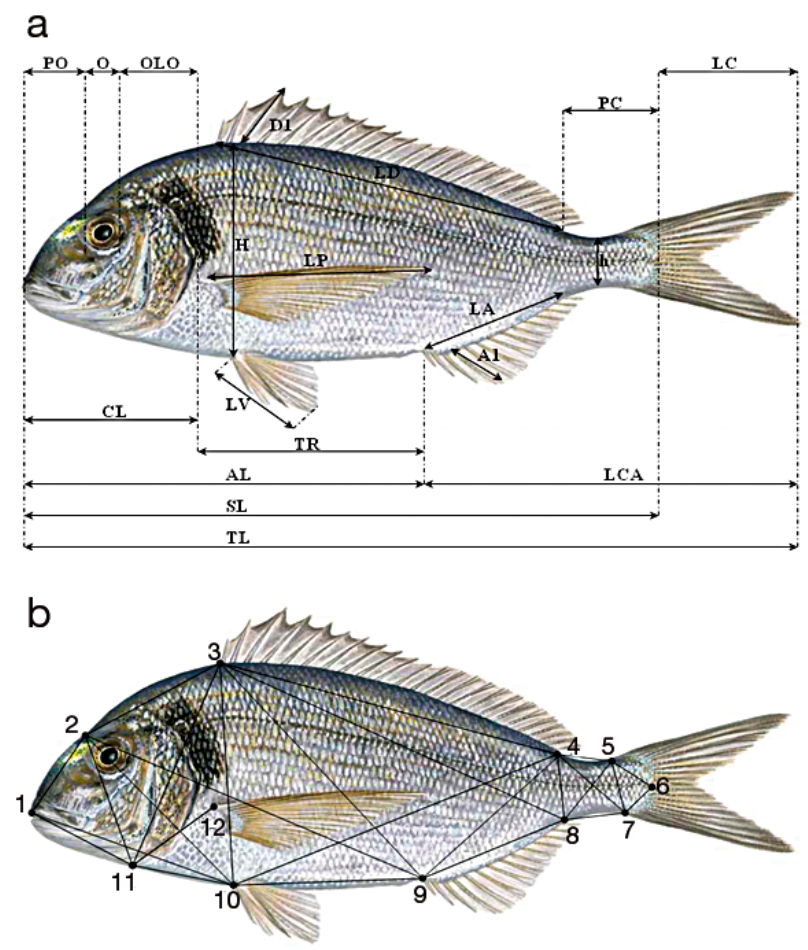

Fig. 2. Schematic drawing of gilthead sea bream (Sparus aurata) body with measured distances and landmarks. (a) Traditional set of measurements (Hubbs \& Lagler 1947) and (b) vectors according to the truss network system (Bookstein 1982). See Table 1 for definitions

\section{DNA extraction and amplification}

DNA was isolated following a simplified mammalian DNA isolation procedure (Laird et al. 1991) and stored in TE buffer. DNA quantity and quality were assessed by spectrophotometry (Eppendorf, Qiagen), and each

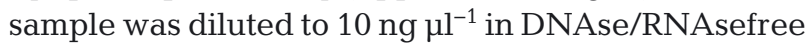
water. A multiplex PCR reaction with the simultaneous amplification of 9 microsatellite loci was used in the study. Primer sequences, concentrations, locus names, and fluorochromes were developed by Navarro et al. (2008), and the following microsatellite markers were used: SauK140INRA (GenBank accession number AY173042), SauD182INRA (AY173034), SauH98INRA (AY173039), PbMS2 (AF209085), SauI47INRA (AY173041), SaI12 (AY322108), PaGA2a (AF202885), SauG46INRA (AY173037), and SauD69 (AY173033). Using the Multiplex PCR kit (Qiagen), amplification of the loci took place in $12.5 \mu \mathrm{l}$ reactions containing 30-50 ng DNA. PCR conditioning involved an initial cycle of denaturation at $95^{\circ} \mathrm{C}$ for 5 min followed by 24 cycles of: denaturation at $95^{\circ} \mathrm{C}$, annealing at $60^{\circ} \mathrm{C}$, and extension at $72^{\circ} \mathrm{C}$ for $30 \mathrm{~s}, 1.5 \mathrm{~min}$, and $30 \mathrm{~s}$, respectively. A final cycle at $60^{\circ} \mathrm{C}$ for 30 min was
Table 1. Sparus aurata. Traditional set of measurements: 19 morphometric characters were measured (drawn in Fig. 2a), and then expressed as ratios to standard length (SL), total length (TL), or head length (CL) (see Table 2 for ratios). Truss network system: 12 morphometric characters were measured and then used to define vectors (drawn in Fig. 2b): 1: tip of premaxillary; 2 : point of maximum curvature in the head profile; 3: anterior insertion of dorsal fin; 4: posterior insertion of dorsal fin; 5 : dorsal point at least depth of caudal peduncle; 6: posterior extremity of lateral line; 7 : ventral point at least depth of caudal peduncle; 8: posterior insertion of anal fin; 9: anterior insertion of anal fin; 10: anterior insertion of pelvic fin; 11: insertion of the operculum on the profile; and 12: dorsal insertion of pectoral fin (modified from Arechavala-Lopez et al. 2012b)

\begin{tabular}{|c|c|c|c|}
\hline \multicolumn{2}{|c|}{$\begin{array}{c}\text { Traditional set of } \\
\text { measurements }\end{array}$} & \multicolumn{2}{|c|}{ Truss network system } \\
\hline Marking & Length & Code & $\begin{array}{l}\text { Morphological } \\
\text { vector }\end{array}$ \\
\hline $\mathrm{TL}$ & Total length & Av1 & $1-2$ \\
\hline $\mathrm{SL}$ & Standard length & A2 & $2-10$ \\
\hline $\mathrm{AL}$ & Anal length & A3 & $10-11$ \\
\hline CL & Head length & A4 & $1-11$ \\
\hline $\mathrm{H}$ & Maximum body height & A5 & $1-10$ \\
\hline $\mathrm{h}$ & Minimum body height & A6 & $2-11$ \\
\hline TR & Trunk & B1 & $2-3$ \\
\hline LCA & Tail & B2 & $3-9$ \\
\hline $\mathrm{LC}$ & Caudal fin length & B3 & $9-10$ \\
\hline LD & Dorsal fin base length & B4 & $2-9$ \\
\hline LP & Pectoral fin length & B5 & $3-10$ \\
\hline $\mathrm{LV}$ & Ventral fin length & B6 & $3-11$ \\
\hline LA & Anal fin base length & $\mathrm{C} 1$ & $3-4$ \\
\hline $\mathrm{PC}$ & Caudal peduncle & $\mathrm{C} 2$ & $4-8$ \\
\hline D1 & Height of dorsal fin & $\mathrm{C} 3$ & $8-9$ \\
\hline A1 & Height of anal fin & $\mathrm{C} 4$ & $3-8$ \\
\hline $\mathrm{PO}$ & Preocular distance & C5 & $4-9$ \\
\hline $\mathrm{O}$ & Eye diameter & $\mathrm{C} 6$ & $4-10$ \\
\hline \multirow[t]{9}{*}{ OLO } & Postocular distance & Dv1 & $4-5$ \\
\hline & & D2 & $5-7$ \\
\hline & & D3 & $7-8$ \\
\hline & & D4 & $4-7$ \\
\hline & & D5 & $5-8$ \\
\hline & & E1 & $5-6$ \\
\hline & & E2 & $6-7$ \\
\hline & & F1 & $1-12$ \\
\hline & & F2 & $11-12$ \\
\hline
\end{tabular}

performed. PCR product $(2 \mu \mathrm{l})$ was mixed with $7.8 \mu \mathrm{l}$ formamide and $0.2 \mu \mathrm{l}$ size standard Liz500. PCR fragments were separated by capillary electrophoresis on an ABI 3130xl Genetic Analyzer. Peak height values for each microsatellite allele were extracted using GeneMapper v.3.5 software (Applied Biosystems).

\section{Analysis of molecular data}

MICRO-CHECKER v.2.2.1 software (van Oosterhout et al. 2004) was used to identify possible geno- 
typing errors such as stuttering, large allele dropout, and null alleles within the microsatellite data set by performing 10000 randomizations. GENEPOP v.3.1b (Raymond \& Rousset 2003) was used to perform an exact test (10000 interactions; Guo \& Thompson 1992) for deviations of genotypic distribution from the expectations of the Hardy-Weinberg equilibrium, to test linkage disequilibrium (LD) for all pairs of loci, to calculate observed $\left(H_{\mathrm{o}}\right)$ and expected $\left(H_{\mathrm{e}}\right)$ heterozygosities, and to test for heterozygosity excess and deficiencies in the microsatellite data. The mean number of alleles per locus $(A)$ and mean effective number of alleles across loci $\left(A_{\mathrm{e}}\right)$ were calculated using POPGENE v.1.32 (Yeh et al. 2000), while allelic richness $\left(A_{\mathrm{r}}\right)$ was calculated using FSTAT v.2.9.3 (Goudet 2002). POWSIM (Ryman \& Palm 2006) was used to assess the statistical power of tests for genetic homogeneity on the applied set of markers and sample sizes. The ARLEQUIN software package (Excoffier \& Lischer 2010) was used to estimate Weir \& Cockerham's (1984) unbiased estimator of Wright's $F$ statistics $\left(F_{\mathrm{ST}}\right)$ and for hierarchical $F_{\mathrm{ST}}$ analyses (analysis of molecular variance [AMOVA], 10000 permutations) on microsatellite data. Genetic differentiation between populations was also calculated using a recently developed alternative measure, $D_{\mathrm{EST}}$ (Jost 2008) as implemented in the program SMOGD (Crawford 2010). The traditional $F_{\mathrm{ST}}$ can underestimate genetic differentiation in situations when high polymorphic markers, such as microsatellites, are employed (Jost 2008, Heller \& Siegismund 2009), and where $F_{\mathrm{ST}}$ values can be observed at values 3-4 times lower than the equivalent statistic Jost's $D_{\text {EST }}$ (Ensing et al. 2011). The Bayesian model-based clustering analysis was used for determining the optimal number of genetic clusters found among gilthead sea bream populations using the software STRUCTURE v.2.3.3 (Pritchard et al. 2000), which partitions individuals into a number of clusters $(K)$ based on the multilocus genotypic data. The admixture model and correlated allele frequencies were applied for each run with a 10000 burn-in period (iteration) and 100000 Markov chain Monte Carlo (MCMC) replications. The optimum $K$ value, which indicates the number of genetically distinct clusters in the data, was determined from 10 replicate runs for each value of $K$ (Evanno et al. 2005). The $\Delta K$ was based on the change in the log probability of the data between successive $K$ values. The Structure Harvester v.6.0 software program (Earl \& von Holdt 2012) was used for calculating the parameters of Evanno et al. (2005). The average pairwise similarity of runs was assessed with the CLUMPP program (Jakobsson \& Rosenberg
2007), with the 'greedy' algorithm, 10000 random input orders, and 10000 repeats. The run with the highest $\Delta K$ was used to construct the dendrogram, which was visualized with the DISTRUCT program (Rosenberg 2004). An individual having more than $70 \%$ of its genome fraction value under a particular $K$ subgroup was assigned to that subgroup. The chosen cut-off was close to optimal for the observed cluster scores distribution, i.e. use of a more stringent cut-off $(80-90 \%)$ resulted in the exclusion of the majority of individuals from both the wild and farmed populations of Mali Ston Bay.

Additionally, stepwise discriminant analysis was conducted on the combined morphological and molecular data set from the Mali Ston Bay subsample, composed of 50 wild and 30 farmed fish. The molecular contribution to the data set was presented as a variable in which each fish was assigned a score derived from the Bayesian cluster analysis. Individuals categorized as admixture forms were excluded from the combined analysis.

\section{RESULTS}

\section{Traditional set of measurements}

Morphometric characteristic ratios and statistical power are given in Table 2. Significant differences between wild and farmed gilthead sea bream Sparus aurata from Mali Ston Bay were observed for 13 of 18 morphometric ratios ( $t$-test, $\mathrm{p}<0.05)$. Based on effect size, morphological differences ranged from medium (ratios for h/SL, LC/SL, LA/SL, PC/SL) to high (ratios for PC/SL, H/SL, LP/SL, D1/SL, O/CL, TR/SL) magnitude with statistical power exceeding 0.80 (Table 2; see Table 1 for abbreviations). Wild and farmed fish showed the greatest differentiation in pectoral fin dimension and height of the dorsal fins. Ratios such as LCA/SL, LV/SL, and A1/SL had statistical power below 0.80 as a result of small effect size, implying low differentiation importance.

Fulton's condition index revealed significant differences ( $t$-test, $t=15.09, \mathrm{p}<0.05)$ between wild $(1.35 \pm$ $0.15)$ and farmed gilthead sea bream $(1.79 \pm 0.16)$, with high magnitude (Cohen's $d=2.73$ ) and statistical power exceeding 0.80 .

\section{Truss network system}

PCA extracted 9 components with eigenvalues greater than 1, explaining $72.6 \%$ of the total vari- 
Table 2. Relationship of measured body dimension ratios from the traditional set of measurements for wild (W), farmed (F), and overall sample (total) of gilthead sea bream Sparus aurata from Mali Ston Bay. CV: coefficient of variation. Asterisks denote significant differences at $p<0.05$ ( $t$-test). See Table 1 for abbreviations

\begin{tabular}{|c|c|c|c|c|c|c|c|}
\hline $\begin{array}{l}\text { Body } \\
\text { proportion }\end{array}$ & Origin & $\begin{array}{c}\text { Range } \\
(\%)\end{array}$ & $\underset{(\%)}{\text { Mean } \pm \text { SD }}$ & $\mathrm{CV}$ & $t$-test & $\begin{array}{l}\text { Effect } \\
\text { size }\end{array}$ & $\begin{array}{l}\text { Stat. } \\
\text { power }\end{array}$ \\
\hline SL/TL & $\begin{array}{c}\mathrm{W} \\
\mathrm{F} \\
\text { Total }\end{array}$ & $\begin{array}{l}72.8-91.1 \\
80.1-86.4 \\
72.8-91.1\end{array}$ & $\begin{array}{l}82.7 \pm 2.5 \\
82.9 \pm 1.3 \\
82.8 \pm 2.2\end{array}$ & $\begin{array}{l}3.03 \\
1.6 \\
2.7\end{array}$ & -0.79 & 0.10 & 0.08 \\
\hline AL/SL & $\begin{array}{c}\mathrm{W} \\
\mathrm{F} \\
\text { Total }\end{array}$ & $\begin{array}{l}53.9-67.6 \\
54.1-61.3 \\
53.9-67.6\end{array}$ & $\begin{aligned} 59.64 & \pm 2.6 \\
57.4 & \pm 1.8 \\
58.9 & \pm 2.6\end{aligned}$ & $\begin{array}{l}4.4 \\
3.1 \\
4.4\end{array}$ & $5.92^{*}$ & 0.98 & 0.99 \\
\hline CL/SL & $\begin{array}{c}\mathrm{W} \\
\mathrm{F} \\
\text { Total }\end{array}$ & $\begin{array}{l}24.2-32.7 \\
24.6-30.4 \\
24.2-32.7\end{array}$ & $\begin{array}{r}28.1 \pm 1.4 \\
27.8 \pm 1.4 \\
28.01 \pm 1.4\end{array}$ & $\begin{array}{l}4.9 \\
5.03 \\
5.01\end{array}$ & 1.18 & 0.21 & 0.21 \\
\hline H/SL & $\begin{array}{c}\mathrm{W} \\
57 \mathrm{~F} \\
\text { Total }\end{array}$ & $\begin{array}{l}31.4-73.9 \\
37.2-42.8 \\
31.4-73.9\end{array}$ & $\begin{array}{l}36.6 \pm 4.3 \\
39.8 \pm 1.3 \\
37.6 \pm 3.9\end{array}$ & $\begin{array}{r}11.7 \\
3.3 \\
10.4\end{array}$ & $-4.89^{*}$ & 1.00 & 0.99 \\
\hline $\mathrm{h} / \mathrm{SL}$ & $\begin{array}{c}\text { W } \\
\text { F } \\
\text { Total }\end{array}$ & $\begin{array}{l}6.9-9.7 \\
7.8-10.4 \\
6.9-10.4\end{array}$ & $\begin{array}{l}8.3 \pm 0.6 \\
8.7 \pm 0.5 \\
8.4 \pm 0.6\end{array}$ & $\begin{array}{l}7.8 \\
6.2 \\
7.7\end{array}$ & $-3.85^{*}$ & 0.65 & 0.94 \\
\hline LCA/SL & $\begin{array}{l}\text { W } \\
\text { F } \\
\text { Total }\end{array}$ & $\begin{array}{l}17.7-67.4 \\
57.9-68.7 \\
17.7-68.7\end{array}$ & $\begin{array}{l}60.6 \pm 5.8 \\
62.8 \pm 2.4 \\
61.3 \pm 5.04\end{array}$ & $\begin{array}{l}9.5 \\
3.7 \\
8.2\end{array}$ & $-3.13^{*}$ & 0.49 & 0.76 \\
\hline LC/SL & $\begin{array}{c}\text { W } \\
\text { F } \\
\text { Total }\end{array}$ & $\begin{array}{l}12.9-53.1 \\
17.5-25.6 \\
12.9-53.1\end{array}$ & $\begin{array}{l}22.9 \pm 3.9 \\
21.4 \pm 1.3 \\
22.4 \pm 3.4\end{array}$ & $\begin{array}{r}17.4 \\
6.2 \\
15.3\end{array}$ & $3.41^{*}$ & 0.51 & 0.80 \\
\hline LD/SL & $\begin{array}{c}\text { W } \\
\text { F } \\
\text { Total }\end{array}$ & $\begin{array}{r}9.1-56.6 \\
45.1-54.1 \\
9.1-56.6\end{array}$ & $\begin{array}{r}51.3 \pm 5.2 \\
50.5 \pm 1.9 \\
51.04 \pm 4.4\end{array}$ & $\begin{array}{r}10.2 \\
3.9 \\
8.7\end{array}$ & 0.89 & 0.20 & 0.19 \\
\hline LP/SL & $\begin{array}{c}\text { W } \\
\text { F } \\
\text { Total }\end{array}$ & $\begin{array}{l}17.6-37.2 \\
19.3-29.4 \\
17.6-37.2\end{array}$ & $\begin{array}{r}31.9 \pm 2.7 \\
25.9 \pm 2.4 \\
30.05 \pm 3.9\end{array}$ & $\begin{array}{r}8.6 \\
9.1 \\
12.9\end{array}$ & $12.73^{*}$ & 2.34 & 1.00 \\
\hline LV/SL & $\begin{array}{c}\text { W } \\
\text { F } \\
\text { Total }\end{array}$ & $\begin{array}{l}14.2-19.3 \\
13.9-17.9 \\
13.9-19.3\end{array}$ & $\begin{array}{l}16.8 \pm 1.1 \\
16.3 \pm 0.9 \\
16.6 \pm 1.04\end{array}$ & $\begin{array}{l}6.2 \\
6.1 \\
6.3\end{array}$ & $2.14^{*}$ & 0.49 & 0.77 \\
\hline LA/SL & $\begin{array}{c}\text { W } \\
\text { F } \\
\text { Total }\end{array}$ & $\begin{array}{l}15.7-25.2 \\
16.7-21.7 \\
15.7-25.2\end{array}$ & $\begin{array}{l}20.1 \pm 1.4 \\
19.3 \pm 1.1 \\
19.9 \pm 1.4\end{array}$ & $\begin{array}{l}7.1 \\
5.9 \\
7.005\end{array}$ & $3.30^{*}$ & 0.71 & 0.97 \\
\hline $\mathrm{PC} / \mathrm{SL}$ & $\begin{array}{c}\text { W } \\
\text { F } \\
\text { Total }\end{array}$ & $\begin{array}{l}10.9-23.3 \\
17.4-23.5 \\
10.9-23.5\end{array}$ & $\begin{array}{l}19.4 \pm 1.9 \\
20.7 \pm 1.6 \\
19.8 \pm 1.9\end{array}$ & $\begin{array}{r}10.2 \\
7.7 \\
9.8\end{array}$ & $-3.57^{*}$ & 0.74 & 0.98 \\
\hline D1/SL & $\begin{array}{c}\text { W } \\
\text { F } \\
\text { Total }\end{array}$ & $\begin{array}{l}8.4-13.5 \\
6.3-10.3 \\
6.3-13.5\end{array}$ & $\begin{array}{r}10.5 \pm 1.1 \\
8.3 \pm 0.9 \\
9.8 \pm 1.5\end{array}$ & $\begin{array}{l}10.9 \\
11.6 \\
15.4\end{array}$ & $11.02^{*}$ & 2.07 & 1.00 \\
\hline A1/SL & $\begin{array}{c}\text { W } \\
\text { F } \\
\text { Total }\end{array}$ & $\begin{array}{l}5.2-19.8 \\
4.9-9.8 \\
4.9-19.8\end{array}$ & $\begin{array}{l}7.9 \pm 1.7 \\
7.2 \pm 1.02 \\
7.7 \pm 1.5\end{array}$ & $\begin{array}{l}21.3 \\
14.2 \\
19.9\end{array}$ & $2.62^{*}$ & 0.50 & 0.77 \\
\hline $\mathrm{PO} / \mathrm{CL}$ & $\begin{array}{c}\text { W } \\
\text { F } \\
\text { Total }\end{array}$ & $\begin{array}{r}28-44.2 \\
29.9-42.5 \\
28-44.2\end{array}$ & $\begin{array}{l}37.04 \pm 3.4 \\
37.04 \pm 2.8 \\
37.04 \pm 3.2\end{array}$ & $\begin{array}{l}9.3 \\
7.5 \\
8.7\end{array}$ & -0.01 & 0.00 & 0.05 \\
\hline $\mathrm{O} / \mathrm{CL}$ & $\begin{array}{c}\text { W } \\
\text { F } \\
\text { Total }\end{array}$ & $\begin{array}{l}13.2-31.7 \\
18.6-28.5 \\
13.2-31.7\end{array}$ & $\begin{array}{l}21.3 \pm 2.9 \\
23.3 \pm 2.3 \\
21.9 \pm 2.9\end{array}$ & $\begin{array}{r}13.7 \\
9.9 \\
13.2\end{array}$ & $-4.02^{*}$ & 0.80 & 0.99 \\
\hline OLO/CL & $\begin{array}{c}\text { W } \\
\text { F } \\
\text { Total }\end{array}$ & $\begin{array}{l}20.4-74.4 \\
41.3-65.4 \\
20.4-74.4\end{array}$ & $\begin{array}{l}51.3 \pm 6.04 \\
51.9 \pm 4.7 \\
51.5 \pm 5.6\end{array}$ & $\begin{array}{r}11.8 \\
9.1 \\
10.9\end{array}$ & -0.66 & 0.11 & 0.09 \\
\hline TR/SL & $\begin{array}{c}\mathrm{W} \\
\mathrm{F} \\
\text { Total }\end{array}$ & $\begin{array}{r}27.02-38.2 \\
25.6-34.8 \\
25.6-38.2\end{array}$ & $\begin{array}{l}32.4 \pm 2.3 \\
30.7 \pm 1.9 \\
31.9 \pm 2.3\end{array}$ & $\begin{array}{l}7.2 \\
6.1 \\
7.2\end{array}$ & $4.17^{*}$ & 0.80 & 0.99 \\
\hline
\end{tabular}

ance. Morphological traits associated with specific components are provided in Table 3. The 4 first components showed the largest differences as they were defined with a minimum of 3 morphological vectors whose component loadings were higher than 0.55. Important differences were principally located in the head measurements, followed by body height and caudal peduncle. Discriminant analysis extracted 1 canonical function explaining $48.4 \%$ of the total variance, since the data was composed of only 2 groups (Table S1 in the Supplement at www.int-res.com/ articles/suppl/q006p043_supp.pdf). Measurements of head and body height (Av1, A6, B1, B5), trunk (B3, C4), and caudal peduncle (E2) were the predictor variables upon which the classification of individuals, wild or farmed, was based (Table S2 in the Supplement). Farmed fish showed higher values in measurements of caudal peduncle (E2), body height (B5), and trunk (B3) in comparison with wild ones. Based on 7 morphological vectors, $12 \%$ of individuals in the wild group were misclassified as farmed, while $15.9 \%$ of individuals for the farmed group were misclassified as wild. In addition, cross-validation analysis incorrectly assigned $16 \%$ of wild fish and $15.9 \%$ of farmed fish.

\section{Analyses of microsatellite allele frequencies}

Based on microsatellite genotype frequencies, only the wild population from Brač Channel (WBC) showed a lack of significant departures from HardyWeinberg equilibrium. Farmed (FMB) and wild populations (WMB) from Mali Ston Bay showed a tendency towards homozygote excess at the loci SauD182 INRA, SauH98INRA, and SauD69, as revealed by Fisher's exact test. The presence of null alleles was not detected. Linkage disequilibrium was observed only in the wild population WMB (between PaGa2a and all other loci, between SauD69 and all other loci in 
Table 3. Sparus aurata. Principal component analysis (PCA) with total variance explained (\%), eigenvalues and component loadings for each morphological vector (from the truss network system; see Table 1 for vector codes) of 9 extracted PCA components with varimax rotation. Component loadings $>0.55$ are shown

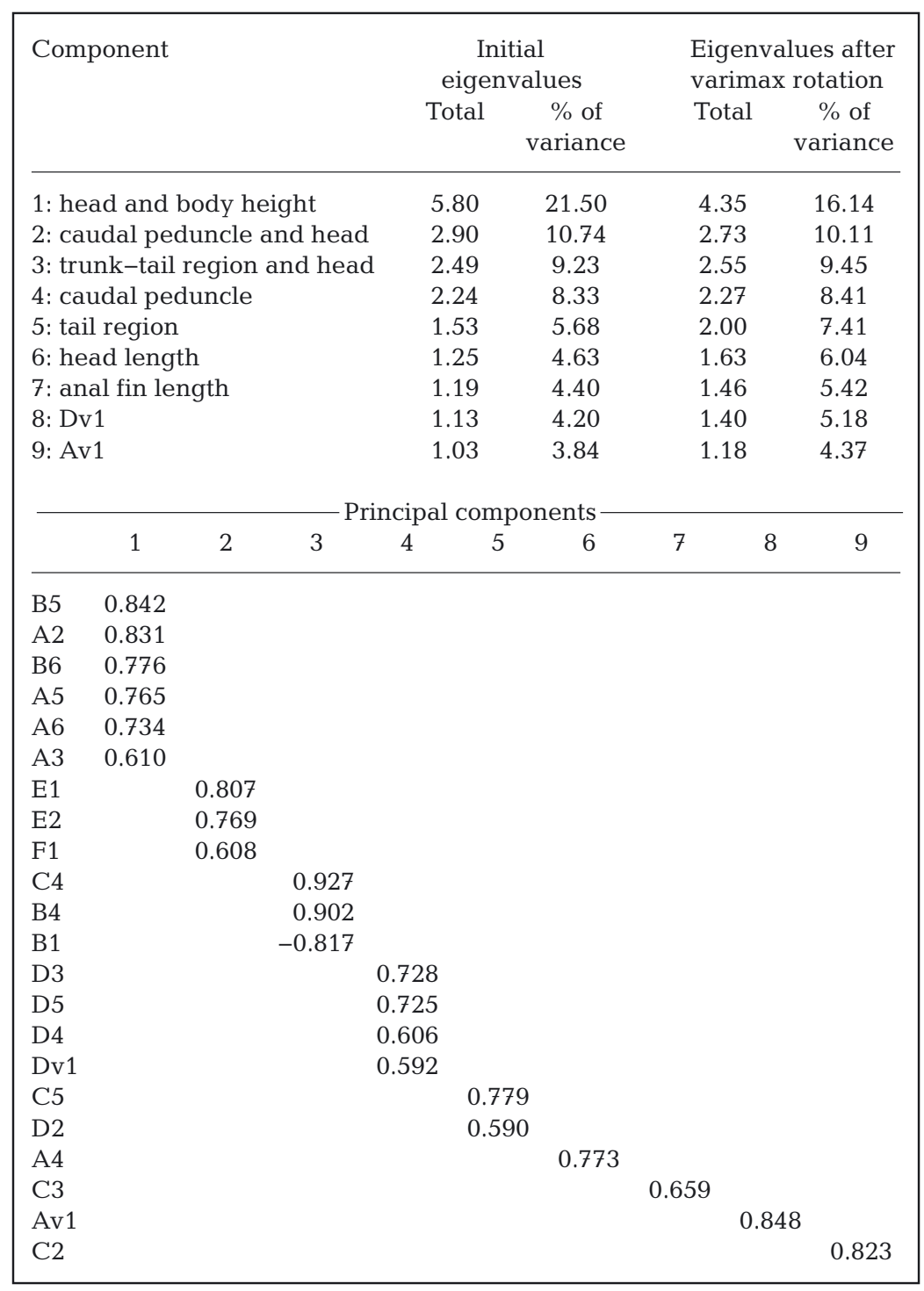

WMB), suggesting limited numbers of progenitors in the sample collection rather than gametic associations for these 2 loci.

All 9 loci were polymorphic with a mean number of alleles $(A)$ greater than 7.8 and mean expected heterozygosity greater than $65 \%$ in all 3 populations (Table 4). The highest $A$ was observed in wild populations, while the lowest was in the farmed population. The effective number of alleles per locus $\left(A_{\mathrm{e}}\right)$ was low (4.8-5.7) relative to $A$ due to the presence of alleles with low frequencies. Additionally, allelic richness, which is a measure of the number of alleles independent of sample size, showed the same trend as $A$. Observed and expected heterozygosity of wild and farmed populations fell within the same range $(0.65-0.69$ and $0.75-$ $0.78)$, respectively. $F_{\mathrm{IS}}$, the inbreeding coefficient, ranged from 0.10 to 0.14 , and was significantly higher than zero for all 3 populations.

The global $F_{\mathrm{ST}}$ value was small but showed significant genetic variation among the gilthead sea bream populations $\left(F_{\mathrm{ST}}=0.017, \mathrm{p}<0.001\right)$, while the global $D_{\text {EST }}$ value was 3 -fold higher (0.055) than the equivalent statistic. Additionally, the power of the microsatellite markers used to detect significant population differentiation was high with simulations in POWSIM, suggesting a probability of $100 \%\left(\chi^{2}\right.$, Fisher's test $)$ of detecting a true differentiation of $F_{\mathrm{ST}}=0.01$ under different scenarios of effective population size $\left(N_{\mathrm{e}}\right)$ and numbers of generations of drift $(t)$ with 1000 replications. The level of population differentiation, as indicated by pairwise $F_{\mathrm{ST}}$ values, was significant only between the farmed population from Mali Ston Bay and the wild population from Brač Channel $\left(F_{\mathrm{ST}}=0.03\right)$. No differentiation was observed between farmed and wild populations from Mali Ston Bay $\left(F_{\mathrm{ST}}=0.019\right)$ or between the wild population from Mali Ston Bay and the wild population from Brač Channel $\left(F_{\mathrm{ST}}=0.011\right)$. The differentiation index $D_{\mathrm{EST}}$ had twice the value for the FMB-WBC interaction (0.06), while other values were consistent with the $F_{\mathrm{ST}}$ values (0.022 for WMB-FMB; 0.013 for WMB-WBC). The absence of a strong genetic structure was confirmed by AMOVA, where less than $1.9 \%$ of the total variance was explained by differences among populations and $98.1 \%$ within populations.

Bayesian clustering analysis and application of the $\Delta \mathrm{K}$ procedure of Evanno et al. (2005) suggested 2 clusters as the most likely population structure (Fig. 3). Of the 110 gilthead sea bream, 90 (81.8\%) shared $>70 \%$ membership with 1 of 2 clusters and were classified as members of that cluster, whereas 
Table 4. Summary statistics for genetic variation of wild and farmed populations of gilthead sea bream Sparus aurata in the Adriatic Sea. FMB, WMB: farmed and wild populations from Mali Ston Bay, southern Adriatic Sea; WBC: wild population from Brač Channel, central Adriatic Sea; $N$ : number of alleles; $A$ : average number of alleles per locus; $A_{\mathrm{e}}$ : effective number of alleles per locus; $A_{\mathrm{r}}$ : allelic richness; $H_{\mathrm{o}}$ : observed heterozygosity; $H_{\mathrm{e}}$ : expected heterozygosity; $F_{\mathrm{IS}}$ : fixation index

\begin{tabular}{|c|c|c|c|c|c|c|c|c|}
\hline \multirow[t]{2}{*}{ Population } & \multirow{2}{*}{$\begin{array}{c}\text { Population } \\
\text { type }\end{array}$} & \multirow[t]{2}{*}{$N$} & \multicolumn{3}{|c|}{ Allele diversity } & \multicolumn{2}{|c|}{ Heterozygosity } & \multirow[t]{2}{*}{$F_{\mathrm{IS}}$} \\
\hline & & & $A$ & $A_{\mathrm{e}}$ & $A_{\mathrm{r}}$ & $H_{\mathrm{o}}$ & $H_{\mathrm{e}}$ & \\
\hline FMB & Farmed & 30 & $7.8 \pm 3.8$ & $4.8 \pm 1.9$ & $7.4 \pm 3.5$ & $0.65 \pm 0.2$ & $0.75 \pm 0.1$ & 0.141 \\
\hline WMB & Wild & 50 & $10.9 \pm 4.7$ & $5.3 \pm 2.9$ & $9.0 \pm 3.6$ & $0.69 \pm 0.2$ & $0.77 \pm 0.1$ & 0.104 \\
\hline WBC & Wild & 30 & $10.0 \pm 4.8$ & $5.7 \pm 3.0$ & $9.5 \pm 4.4$ & $0.69 \pm 0.3$ & $0.78 \pm 0.1$ & 0.122 \\
\hline Overall & & 110 & $12.8 \pm 6.1$ & $5.7 \pm 2.9$ & $9.5 \pm 3.8$ & $0.68 \pm 0.2$ & $0.78 \pm 0.1$ & \\
\hline
\end{tabular}

\section{Southern Adriatic (farmed)}

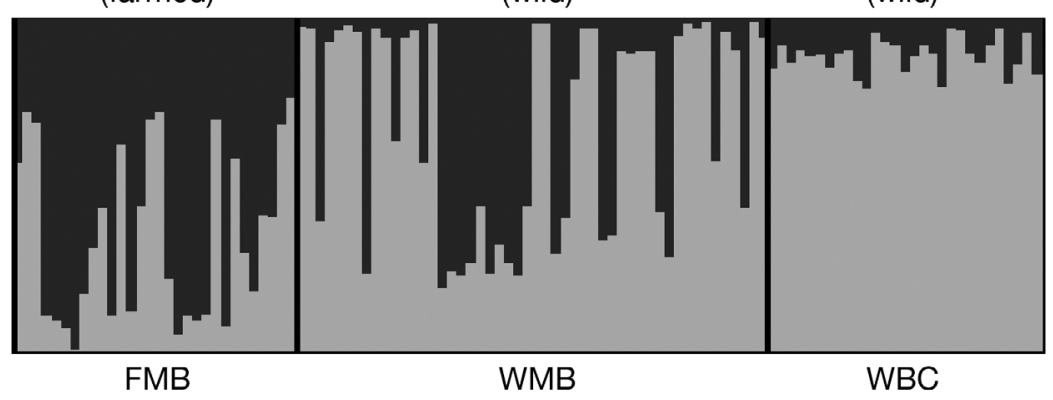

Fig. 3. Proportional membership of each individual gilthead sea bream Sparus aurata from the Adriatic Sea in 2 clusters identified by the software STRUCTURE. Regional subdivision (above the graph) and origin locality of each individual (below the graph) are indicated. See Table 4 for abbreviations and $8 \%$ misclassified in the farmed group (2/25 wild-like shape). At the individual fish level, all morphologically misclassified individuals were also misclassified using the Bayesian clustering analysis, although molecular analysis noted an additional 4 potential escapees and 1 wild-like individual (Table S3 in the Supplement). Thus, the combined discriminant analysis revealed $20 \%$ misclassified individuals in the wild group (8/40 potential escapees) and $12 \%$ misclassified in the farmed group (3/25 wild-like shape).
20 individuals $(18.2 \%)$ were categorized as admixture forms with varying levels of membership shared between the 2 clusters. Cluster 1 contained the wild individuals from the central Adriatic (WBC, Brač Channel) and the southern Adriatic (WMB, Mali Ston Bay), with a proportion of membership to Cluster 1 of 0.89 and 0.69 , respectively. Farmed individuals from the southern Adriatic (FMB, Mali Ston Bay) were assigned to Cluster 2, with a proportion of membership of 0.65 . Ten farmed individuals belonged to Cluster 1 (25\% of cluster membership), which was constituted mainly of wild individuals, and as such, may represent potential escapees. Only 3 wild individuals were assigned to Cluster $2(12 \%$ of cluster membership), which was formed mainly of farmed individuals.

When molecular data was added to the morphological data in the combined analysis, increased resolution of potential escapees was detected in comparison to the morphological data alone. Namely, discriminant analysis of morphological data from the Mali Ston Bay subsample denoted 15\% misclassified individuals in the wild group (6/40 potential escapees)

\section{DISCUSSION}

For the first time, molecular and morphological tools were combined in order to identify differences between wild and farmed sea bream Sparus aurata from Mali Ston Bay and to detect recent escapees in local wild populations. The results demonstrated discordance between the levels of morphological and genetic divergence. There were significant morphological differences between wild and farmed individuals. Farmed gilthead sea bream were characterized by a stocky body with a flattened head profile and shorter fins in comparison to wild individuals, which had an elongated body with smaller body depth. A traditional set of measurements noted significant differences in pectoral fin dimensions, height of the dorsal fins, body height, anal distance, and trunk and eye diameters. The truss network system identified measurements of head and body depth, trunk-tail region, and caudal peduncle as those of primary importance in distinguishing wild from farmed gilthead sea bream. Similar results were noted in other Mediterranean countries, summarized in Table S4 (in the Supplement 
at www.int-res.com/articles/suppl/q006p043_supp.pdf). Morphological traits are influenced by habitat features, sampling period, broodstock origin, or selective breeding programs applied in aquaculture (Karaiskou et al. 2009, Rogdakis et al. 2011). The stocky body in farmed fish can be attributed to intensive feeding during the summer season (Hurtado-Rodriguez et al. 2010), as confirmed by significantly different values of the Fulton's condition index between farmed and wild fish. Also, the stocky body shape of reared gilthead sea bream is greatly determined by selection programs applied in hatcheries. Comparative morphology between wild and farmed gilthead sea bream in the Mediterranean confirmed that the majority of producers target a body shape with a higher body height (H/SL, B5) (Brown 2003, Hurtado-Rodriguez et al. 2010, Rogdakis et al. 2011, Arechavala-Lopez et al. $2012 \mathrm{~b}$ ). The indirect result of such selection may be the reduction of anal length (AL/SL) and trunk length (TR/SL) in farmed fish, which consequently leads to a longer tail (LCA/SL) (see Tables 1 \& 2 for abbreviations and ratios).

Reduced fin dimensions in the farmed fish are associated with their rearing conditions and influences swimming performance (Başaran et al. 2007, Hanson et al. 2007). The volume and hydrodynamics of floating sea cages, stock density, absence of predators, and everyday availability of food lead to decreased use of locomotor repertoires. In this study, the head characteristics differentiating wild and farmed gilthead sea bream were more related to the profile of the head rather than head length; farmed fish were characterized by a flattened head shape in comparison to wild gilthead sea bream. Four different head shapes (i.e. normal, pointed, flattened, and rounded) were observed in farmed gilthead sea bream (Brown 2003). Furthermore, different broodstock origins have shown different head shapes throughout the Mediterranean, i.e. with a rounded snout with slight prognathism (Grigorakis et al. 2002), longer head (Rogdakis et al. 2011), and smaller snout (Arechavala-Lopez et al. 2012b) in comparison to wild fish. These shapes may be related to different parental phenotypes; however, their use as selection criteria is limited (Brown 2003).

Molecular analysis revealed weak neutral genetic differentiation among the farmed and wild sea bream samples from Mali Ston Bay $\left(F_{\mathrm{ST}}=0.019, \mathrm{p}>\right.$ $0.05 ; D_{\mathrm{EST}}=0.022$ ). The genetic markers used for this study showed significant genetic differentiation between the central and southern wild Adriatic populations $\left(F_{\mathrm{ST}}=0.03, \mathrm{p}<0.05\right)$, and, therefore, a lack of differentiation was not due to low marker power. An equivalent comparison with the estimator of actual differentiation $D_{\text {EST }}$ indicated twice the level of differentiation among these populations (0.06). Hence, the analysis suggests the presence of escapees in wild populations of Mali Ston Bay.

The long culture period carried out over the past decade may have contributed to wild population homogenization, as was reported for wild populations sampled along the Italian coast (Franchini et al. 2012) and in Atlantic salmon (Glover et al. 2012). However, the population structure of gilthead sea bream is still unclear and does not appear to be associated with geographic or oceanographic factors (Alarcón et al. 2004, Ben Slimen et al. 2004, De Innocentiis et al. 2004, Rossi et al. 2006). Alarcón et al. (2004) suggested that the high dispersal capacity of this species may produce a high exchange of migrants among subpopulations, thus allowing a large effective subpopulation size and low structuring. Therefore, the application of molecular markers represented a challenge in detecting escapees, since genetic interactions between wild and farmed fish originating from allochthonous breeders (i.e. France, Italy) has already been noted in the southern Adriatic, thus causing a highly admixed wild population structure (Šegvić-Bubić et al. 2011a).

In the present study, only the central Adriatic wild population was in Hardy-Weinberg equilibrium; it was chosen as a control population, as it was known from a previous study that aquaculture activity and genetic introgression of farmed escapees in that wild population were negligible (Šegvić-Bubić et al. 2011a). Observed deviations from Hardy-Weinberg equilibrium in wild and farmed southern populations reflect non-random mating and population mixing. Non-random breeding and low effective population size is a typical scenario in hatcheries where nongenetic management occurs (Borrell et al. 2007, Castro et al. 2007, Karaiskou et al. 2009). This interpretation is further supported by a lower average number of alleles per locus and allelic richness in reared versus wild populations, something also observed for other aquaculture species such as Atlantic salmon (e.g. Skaala et al. 2004). Homozygote excess observed in wild populations can be attributed to the Wahlund effect (Rosenberg \& Calabrese 2004), though inbreeding events cannot be excluded.

From the collected genotypes, the model-based structure analysis separated wild and farmed individuals into 2 distinct populations, where wild individuals from the control population were $100 \%$ correctly assigned, with the exclusion of genotypes that shared less than $70 \%$ membership. The presence of 
$25 \%$ farmed individuals in the cluster formed of wild individuals could indicate possible escapees. However, through discriminant analysis of total morphological data, only $16 \%$ of wild individuals were misclassified as farmed (cross-validation analysis). The combined morphological and genetic analyses indicated that an integrated approach can increased resolution of misclassified individuals in comparison to the morphological data alone, but still not as sufficiently well as molecular markers alone. Namely, at the individual fish level, all morphologically misclassified individuals were also misclassified using Bayesian clustering analysis, although molecular analysis noted an additional 4 potential escapees and 1 wild-like individual.

From a morphological point of view, the observed disproportion in farmed fish classification could be attributed to phenotypic plasticity caused by environmental variation. Rogdakis et al. (2011) revealed that hatchery-released gilthead sea bream configured a wild-like shape after a 6-7 mo period in a wild habitat. This is acclimatization with morphological changes following reduced feed abundance and higher swimming activity. If misclassified farmed individuals from the genetic analysis represent real escapees, it could be argued that morphometry analysis is primarily sensitive in the detection of recent escapee events, i.e. before acclimatization has normalized body proportions. In addition, $16 \%$ of farmed individuals were classified into the group of individuals of wild origin. Observed malformations of the caudal peduncle region that are common anomalies in hatchery-reared larvae (Boglione et al. 2001) may be responsible for this misclassification, as the main predictor variable (E2) for the farmed individuals had negative values in the PCA scores.

The question remains as to targeting the traceability power of neutral molecular markers and the ability to detect farmed genotypes in escaped offspring and in further generations, where admixed wild and farmed genotypes occur (Besnier et al. 2011). Thus, those non-classified individuals $(18.2 \%)$ from the Bayesian analysis having membership in both groups could have been offspring from farmed escapees or crosses between wild and escaped farmed fish. Using neutral markers, Glover et al. (2011) pointed out that identification of Atlantic cod Gadus morhua L. escapees using microsatellite markers could become complicated in situations of weak population differentiation among groups of fish reared in different farms and cages, when fish is farmed in the same region where its parents/grandparents were initially sourced, or when the farmed escapees originated from multiple sources. Thus, Glover et al. (2011) propose using novel type-diagnostic markers such as single nucleotide polymorphisms (SNPs) to elucidate and quantify genetic interactions fully, which are already successfully utilized in salmon escapee detection (Karlsson et al. 2011, Glover et al. 2013).

In conclusion, clear body shape differences of wild and farmed gilthead sea bream were observed using both morphological differentiation techniques. A traditional set of measurements proved to be a practical technique in the field where specific traits can be easily sampled using morphometric ratios. Using the assignment test, morphological and molecular analysis identified farmed escapees in the wild data set sampled in the vicinity of aquaculture sites. Despite a mixed gene pool in the wild population, as a result of a long-term culture period of fish originating from Atlantic broodstocks, the molecular genetics tools identified potential farmed escapees in the sea in Mali Ston Bay. Therefore, verification of escapees and their genetic interaction with wild conspecifics is required both here and in other aquaculture sites along the Adriatic coast. In addition, morphological data showed good potential for distinguishing recently escaped individuals among wild populations, since the method is based on characteristics affected by the environment.

Local fisheries play a major role in the removal of individuals escaped from farms (Arechavala-Lopez et al. 2012a), though their activities are excluded within the boundaries of an MPA such as Mali Ston Bay. This, combined with the ability of gilthead sea bream to adapt to wild environments, leads to increased survival rates of escapees. High gilthead sea bream predation on mussel farms along the Croatian coastline (Šegvić-Bubić et al. 2011b) indicates that escaped individuals greatly contribute to heavy losses of mussels. In the situations where mussel farms in Mali Ston Bay are subjected to strong gilthead sea bream predation due to the interaction of different types of aquaculture (finfish vs. mussels), which is especially enhanced in MPAs, both diagnostic tools can be useful in controlling escapee events. Nevertheless, studies are needed to shed light on the interactions among different coastal users, which could improve actual aquaculture site selection procedures. Furthermore, improvement and standardization of fish farm equipment leading to a reduction in the numbers of escapees, the obligation of reporting escape events, and, finally, the development of sterile farmed fish, are future steps that should be implemented in national legislation to promote sustainable aquaculture and healthy wild stocks. 
Acknowledgements. We are thankful for the detailed and constructive suggestions and comments of the anonymous reviewers that made the manuscript more concise and fluent.

\section{LITERATURE CITED}

Alarcón JA, Magoulas A, Georgakopoulos T, Zouros E, Alvarez MC (2004) Genetic comparison of wild and cultivated European populations of the gilthead sea bream (Sparus aurata). Aquaculture 230:65-80

Arechavala-Lopez P, Uglem I, Fernandez-Jover D, BayleSempere JT, Sanchez-Jerez P (2011) Immediate postescape behaviour of farmed sea bass (Dicentrarchus labrax) in the Mediterranean Sea. J Appl Ichthyol 27: 1375-1378

Arechavala-Lopez P, Uglem I, Fernandez-Jover D, BayleSempere JT, Sanchez-Jerez P (2012a) Post-escape dispersion of farmed sea bream (Sparus aurata L.) and recaptures by local fisheries in the Western Mediterranean Sea. Fish Res 121-122:126-135

> Arechavala-Lopez P, Sanchez-Jerez P, Bayle-Sempere J, Sfakianakis D, Somarakis S (2012b) Morphological differences between wild and farmed Mediterranean fish. Hydrobiologia 679:217-231

Arechavala-Lopez P, Fernandez-Jover D, Kenneth DB, Ladoukakis E, Bayle-Sempere JT, Sanchez-Jerez P, Dempster T (2013) Differentiating the wild or farmed origin of Mediterranean fish: a review of tools for sea bream and sea bass. Rev Aquacult 5:137-157

Başaran F, Ozbilgin H, Ozbilgin YD (2007) Comparison of the swimming performance of farmed and wild gilthead sea bream, Sparus aurata. Aquacult Res 38:452-456

Ben Slimen H, Guerbej H, Ben Othmen A, Ould Brahin I and others (2004) Genetic differentiation between populations of gilthead sea bream (Sparus aurata) along the Tunisian coast. Cybium 28:45-50

> Besnier F, Glover KA, Skaala O (2011) Investigating genetic change in wild populations: modelling gene flow from farm escapees. Aquacult Environ Interact 2:75-86

Boglione C, Gagliardi F, Scardi M, Stefano C (2001) Skeletal descriptors and quality assessment in larvae and postlarvae of wild-caught and hatchery-reared gilthead sea bream (Sparus aurata L. 1758). Aquaculture 192:1-22

Bookstein FL (1982) Foundations of morphometrics. Annu Rev Ecol Syst 13:451-470

Borrell YJ, Carleos CE, Asturiano JF, Bernardo D and others (2007) Use of microsatellites and a combinatorial optimization approach in the acquisition of gilthead seabream (Sparus aurata L.) broodstocks for hatcheries. Aquaculture 269:200-210

Brown RC (2003) Genetic management and selective breeding in farmed populations of gilthead sea bream (Sparus aurata). PhD dissertation, University of Stirling

- Castro J, Pino A, Hermida M, Bouza C and others (2007) A microsatellite marker tool for parentage assessment in gilthead seabream (Sparus aurata). Aquaculture 272(Suppl 1):S210-S216

Cohen J (1992) A power primer. Psychol Bull 112:155-159

> Crawford NG (2010) SMOGD: software for the measurement of genetic diversity. Mol Ecol Resour 10:556-557

Croatian Bureau of Statistics (2013) Seawater Fishing 2012, First Release No. 1.4.1. www.dzs.hr

> De Innocentiis S, Lesti A, Livi S, Rossi AR, Crosetti D, Sola L (2004) Microsatellite markers reveal population structure in gilthead sea bream Sparus auratus from the Atlantic Ocean and Mediterranean Sea. Fish Sci 70:852-859

Dimitriou E, Katselis G, Moutopoulos DK, Akovitiotis C, Koutsikopoulos C (2007) Possible influence of reared gilthead sea bream (Sparus aurata L.) on wild stocks in the area of the Messolonghi Lagoon (Ionian Sea, Greece). Aquacult Res 38:398-408

Earl DA, von Holdt BM (2012) STRUCTURE HARVESTER: a website and program for visualizing STRUCTURE output and implementing the Evanno method. Conserv Genet Resour 4:359-361

> Ensing D, Prodöhl PA, McGinnity $\mathrm{P}$, Boylan $\mathrm{P}$, O'Maoiléidigh N, Crozier WW (2011) Complex pattern of genetic structuring in the Atlantic salmon (Salmo salar L.) of the River Foyle system in northwest Ireland: disentangling the evolutionary signal from population stochasticity. Ecol Evol 1:359-372

Evanno G, Regnaut S, Goudet J (2005) Detecting the number of clusters of individuals using the software STRUCTURE: a simulation study. Mol Ecol 14:2611-2620

Excoffier L, Lischer HE (2010) Arlequin suite, version 3.5: a new series of programs to perform population genetics analyses under Linux and Windows. Mol Ecol Resour 10: 564-567

FAO (Food and Agriculture Organization of the United Nations) (2013) FishStat Plus - universal software for fishery statistical time series (online or CD-ROM). www.fao.org/fishery/statistics/software/fishstat/en

FEAP (Federation of European Aquaculture Producers) (2013) European Aquaculture Production Report 20032012. FEAP Secretariat, Liége. www.aquamedia.org

Franchini P, Sola L, Crosetti D, Milana V, Rossi AR (2012) Low levels of population genetic structure in the gilthead sea bream, Sparus aurata, along the coast of Italy. ICES J Mar Sci 69:41-50

Glover KA (2010) Forensic identification of fish farm escapees: the Norwegian experience. Aquacult Environ Interact 1:1-10

Glover KA, Skilbrei OT, Skaala $\varnothing$ (2008) Genetic assignment identifies farm of origin for a group of farmed escaped salmon in a Norwegian fjord. ICES J Mar Sci 65: 912-920

Glover KA, Dahle G, Jørstad KE (2011) Genetic identification of farmed and wild Atlantic cod, Gadus morhua, in coastal Norway. ICES J Mar Sci 68:901-910

> Glover KA, Quintela M, Wennevik V, Besnier F, Sørvik AGE, Skaala Ø (2012) Three decades of farmed escapees in the wild: a spatio-temporal analysis of Atlantic salmon population genetic structure throughout Norway. PLoS ONE 7:e43129

> Glover KA, Pertoldi C, Besnier F, Wennevik V, Kent M, Skaala $\varnothing$ (2013) Atlantic salmon populations invaded by farmed escapees: quantifying genetic introgression with a Bayesian approach and SNPs. BMC Genet 14:74

Goudet J (2002) FSTAT, a program to estimate and test gene diversities and fixation indices (version 2.9.3.2). www2. unil.ch/popgen/softwares/fstat.htm

> Grigorakis K, Rigos G (2011) Aquaculture effects on environmental and public welfare - the case of Mediterranean mariculture. Chemosphere 85:899-919

> Grigorakis K, Alexis MN, Taylor KDA, Hole M (2002) Comparison of wild and cultured gilthead sea bream (Sparus aurata); composition, appearance and seasonal variations. Int J Food Sci Technol 37:477-484

Guo SW, Thompson EA (1992) Performing the exact test of 
Hardy-Weinberg proportion for multiple alleles. Biometrics 48:361-372

Hanson KC, Hasler CT, Suski CD, Cooke SJ (2007) Morphological correlates of swimming activity in wild largemouth bass (Micropterus salmoides) in their natural environment. Comp Biochem Physiol A 148:913-920

- Heller R, Siegismund HR (2009) Relationship between three measures of genetic differentiation $G_{\mathrm{ST}}, D_{\mathrm{EST}}$ and $G_{\mathrm{ST}}$ : How wrong have we been? Mol Ecol 18:2080-2083

Hubbs CL, Lagler KF (1947) Fishes of the Great Lakes region. Cranbrook Inst Sci Bull 26. Cranbrook Press, Bloomfield Hills, MI

Hurtado-Rodriguez R, Fountoulaki E, Grigorakis K, Alexis M, Flos R (2010) Season and size effects: changes in the quality of gilthead sea bream (Sparus aurata L.). Mediterr Mar Sci 11:117-131

> Jakobsson M, Rosenberg NA (2007) CLUMPP: a cluster matching and permutation program for dealing with label switching and multimodality in analysis of population structure. Bioinformatics 23:1801-1806

Jonsson B, Jonsson N (2006) Cultured Atlantic salmon in nature: a review of their ecology and interaction with wild fish. ICES J Mar Sci 63:1162-1181

> Jost L (2008) $\mathrm{G}_{\mathrm{ST}}$ and its relatives do not measure differentiation. Mol Ecol 17:4015-4026

Karaiskou N, Triantafyllidis A, Katsares V, Abatzopoulos TJ, Triantaphyllidis C (2009) Microsatellite variability of wild and farmed populations of Sparus aurata. J Fish Biol 74:1816-1825

Karlsson S, Moen T, Liem S, Glover KA, Hindar K (2011) Generic genetic differences between farmed and wild Atlantic salmon identified from a 7K SNP-chip. Mol Ecol Resour 11:247-253

Laird PW, Zijderveld A, Linders K, Rudnicki MA, Jaenisch R, Berns A (1991) Simplified mammalian DNA isolation procedure. Nucleic Acids Res 19:4293

Loukovitis D, Sarropoulou E, Vogiatzi E, Tsigenopoulos CS, Kotoulas G, Magoulas A, Chatziplis D (2012) Genetic variation in farmed populations of the gilthead sea bream Sparus aurata in Greece using microsatellite DNA markers. Aquacult Res 43:239-246

McHugh ML (2008) Power analysis in research. Biochem Med 18:263-274

Miggiano E, De Innocentiis S, Ungaro A, Sola L, Crosetti D (2005) AFLP and microsatellites as genetic tags to identify cultured gilthead sea bream escapees: data from a simulated floating cage breaking event. Aquacult Int 13: 137-146

Navarro A, Badilla R, Zamorano MJ, Pasamontes V, Hildebrandt S, Sánchez JJ, Afonso JM (2008) Development of two new microsatellite multiplex PCRs for three sparid species: gilthead seabream (Sparus auratus L.), red porgy (Pagrus pagrus L.) and redbanded seabream ( $P$.

Editorial responsibility: Kevin Glover,

Bergen, Norway auriga, Valenciennes, 1843) and their application to paternity studies. Aquaculture 285:30-37

Pritchard J, Stephens M, Donnelly P (2000) Inference of population structure using multilocus genotype data. Genetics 155:945-959

Raymond M, Rousset F (2003) A population genetic software for exact test and ecumenicism: GENEPOP, version 3.4. Heredity 68:248-249

> Reist JD (1985) An empirical evaluation of several univariate methods that adjust size variation in morphometric data. Can J Zool 63:1429-1439

Rogdakis Y, Koukou K, Ramfos A, Dimitriou E, Katselis G (2011) Comparative morphology of wild, farmed and hatchery-released gilthead sea bream (Sparus aurata) in western Greece. Int J Fish Aquacult 3:1-9

Rosenberg NA (2004) Distruct: a program for the graphical display of population structure. Mol Ecol Notes 4:137-138

Rosenberg NA, Calabrese PP (2004) Polyploid and multilocus extensions of the Wahlund inequality. Theor Popul Biol 66:381-391

Rossi R, Perrone E, Sola L (2006) Genetic structure of gilthead seabream, Sparus aurata, in the Central Mediterranean Sea. Cent Eur J Biol 1:636-647

Ryman N, Palm S (2006) POWSIM: a computer program for assessing statistical power when testing for genetic differentiation. Mol Ecol 6:600-602

Šegvić-Bubić T, Lepen I, Trumbić Ž, Ljubković J and others (2011a) Population genetic structure of reared and wild gilthead sea bream (Sparus aurata) in the Adriatic Sea inferred with microsatellite loci. Aquaculture 318:309-315

Šegvić-Bubić T, Grubišić L, Karaman N, Tičina V, Mišlov JK, Katavić I (2011b) Damages on mussel farms potentially caused by fish predation - self service on the ropes? Aquaculture 319:497-504

Skaala Ø, Høyheim B, Glover KA, Dahle G (2004) Microsatellite analysis in domesticated and wild Atlantic salmon (Salmo salar L): allelic diversity and identification of individuals. Aquaculture 240:131-143

Skaala Ø, Wennevik V, Glover KA (2006) Evidence of temporal genetic change in wild Atlantic salmon (Salmo salar L.) populations affected by farmed escapees. ICES J Mar Sci 63:1224-1233

> van Oosterhout C, Hutchinson WF, Wills DPM, Shipley P (2004) MICRO-CHECKER: software for identifying and correcting genotyping errors in microsatellite data. Mol Ecol Notes 4:535-538

- Weir B, Cockerham C (1984) Estimating F statistics for the analysis of population structure. Evolution 38:1358-1370

Yeh F, Yang R, Boyle T (2000) POPGENE, version 1.32: a Microsoft Windows-based freeware for population genetic analysis. Molecular Biology and Biotechnology Centre, University of Alberta, Edmonton. www.ualberta. ca/ fyeh/popgene.htm

Submitted: December 18, 2013; Accepted: August 26, 2014 Proofs received from author(s): October 24, 2014 